\title{
O(s) Prémio(s) da Crítica 2004
}

\section{Paulo Eduardo Carvalho}

A atribuição de prémios nos domínios da criação artística é sempre um procedimento delicado. $E_{1}$ contudo, eles abundam. Em Portugal, a situação apresenta contornos particulares, nem todos eles muito auspiciosos no que diz respeito ao teatro. Após algumas décadas em que se acumulavam os prémios da própria APCT com os Prémios Garrett, os Setes de Ouro e os Troféus Nova Gente, ou ainda os prémios TV Guia e os Prémios Antena Um, quase todos eles contemplando as múltiplas e variadas categorias de intervenção na criação teatral e pautados pela sempre discutivel sugestão de que se premiava o "melhor", encontramonos, em anos mais recentes, numa situação de clara rarefacção ou especialização das distinções consagradas à criação teatral: os Prémios Almada e Revelação Ribeiro da Fonte, os Prémios ACARTE/ Madalena de Azeredo Perdição, os Prémios do Teatro na Década ou este mais recente Prémio da Crítica traduzem todos eles a dificuldade de dar conta, de forma que desejariamos exaustiva e abrangente, de experiências não só diversificadas, mas também cada vez mais fragmentadas e atomizadas e mais amplamente distribuidas pelo território nacional, sujeitas a períodos de apresentação consideravelmente curtos, razões de sobra para tornar muito dificil uma qualquer distinção valorativa por categorias.

Além disso, a importância de um prémio resulta não só da qualidade historicamente comprovada dos seus contemplados, mas também da sua própria longevidade. Em Portugal, a atávica brevidade das diversas experiências, acima referidas, destes últimos trinta anos não conseguiu criar nada com um prestígio equivalente aos britânicos Evening Standard ou Olivier, aos Lope de Vega espanhóis ou aos Molière franceses. Claro que, entre nós, os prémios teatrais não têm qualquer efeito no marketing do espectáculo, afirmando-se unicamente como tributos genuinos, como sinais de aprovação e celebração. E justamente porque queremos continuar a "criticamente" celebrar a criação cénica, também nós, na renascida Associação Portuguesa de Críticos de Teatro, achámos que valia a pena recomeçar.

De acordo com o regulamento aprovado no início de 2003, o Prémio da Crítica destina-se a distinguir "uma invulgar contribuição para o panorama artístico nacional" no domínio das artes performativas, contemplando ainda a possibilidade de atribuição de três Menções Especiais, sujeitas ao mesmo tipo de consideração. No ano passado, atribuímos o Prémio da Crítica à tradutora e dramaturgista Vera San Payo de Lemos, distribuindo as três Menções Especiais pelo projecto Percursos, uma iniciativa do Serviço de Pedagogia e Animação do CCB, coordenado por Madalena
Victorino e Giacomo Scalisi, pelo espectáculo Circo, do Teatro da Garagem, escrito e encenado por Carlos J. Pessoa, e pelo sonoplasta e desenhador de som Francisco Leal.

Nesta segunda edição, decidiu um júri constituído por João Carneiro, Maria Helena Serôdio, Miguel-Pedro Quadrio, Mónica Guerreiro e por mim próprio, atribuir o Prémio da Crítica 2004 ao espectáculo Para além do Tejo, uma criação de Miguel Seabra, co-produzido pelo Teatro Meridional e pelo CCB. Decidiu ainda este júri atribuir três Menções Especiais a três outros espectáculos, aqui apresentados pela sua ordem de estreia: o espectáculo 0 fazedor de teatro, texto de Thomas Bernhard, com encenação de Joaquim Benite e produção da Companhia de Teatro de Almada; o espectáculo Luz/Interior, um projecto de Rita Só, co-produzido pela Casa Conveniente e por João Garcia Miguel Unipessoal; e ainda o espectáculo A cabra, ou quem é Silvia?, texto de Edward Albee, encenação de Álvaro Correia e produção d'A Comuna - Teatro de Pesquisa.

Tal como já aconteceu o ano passado - e esta será a mais assumida diferença destes prémios - a cerimónia pública de entrega dos nossos humildes, embora originais, troféus foi acompanhada pela mais discursiva expressão dos méritos muito diversos reconhecidos às realidades distinguidas. Assim, cada um dos espectáculos foi objecto de uma breve reflexão, empenhada em desenvolver e justificar as nossas opções, deste modo contribuindo também - assim o esperamos - para a ampliação crítica dos méritos reconhecidos aos premiados.

Com base na divisão de tarefas realizada aquando da reunião do júri, coube a Maria Helena Serôdio assegurar o texto de apresentação do espectáculo Para além do Tejo, a Miguel-Pedro Quadrio o comentário de 0 fazedor de teatro, a Mónica Guerreiro apresentar Luz/Interior, e a João Carneiro falar de A cabra, ou quem é Silvia? Tal como já aconteceu o ano passado, para além de algumas tímidas recomendações em termos de extensão, os textos que se seguem resultam das abordagens muito pessoais características de cada um dos intervenientes, agilizadas em função do seu próprio entendimento das realidades artísticas distinguidas.

Resta acrescentar que, devido ao amável e eficiente empenho do director do Teatro Nacional D. Maria II, António Lagarto, a cerimónia de entrega destes prémios, realizou-se no Salão Nobre daquele Teatro, no dia 28 de Março de 2005. A ela assistiu o Senhor Secretário de Estado da Cultura, Professor Mário Vieira de Carvalho, e durante a sessão foi lida uma primeira versão dos textos que agora, aqui, publicamos. 


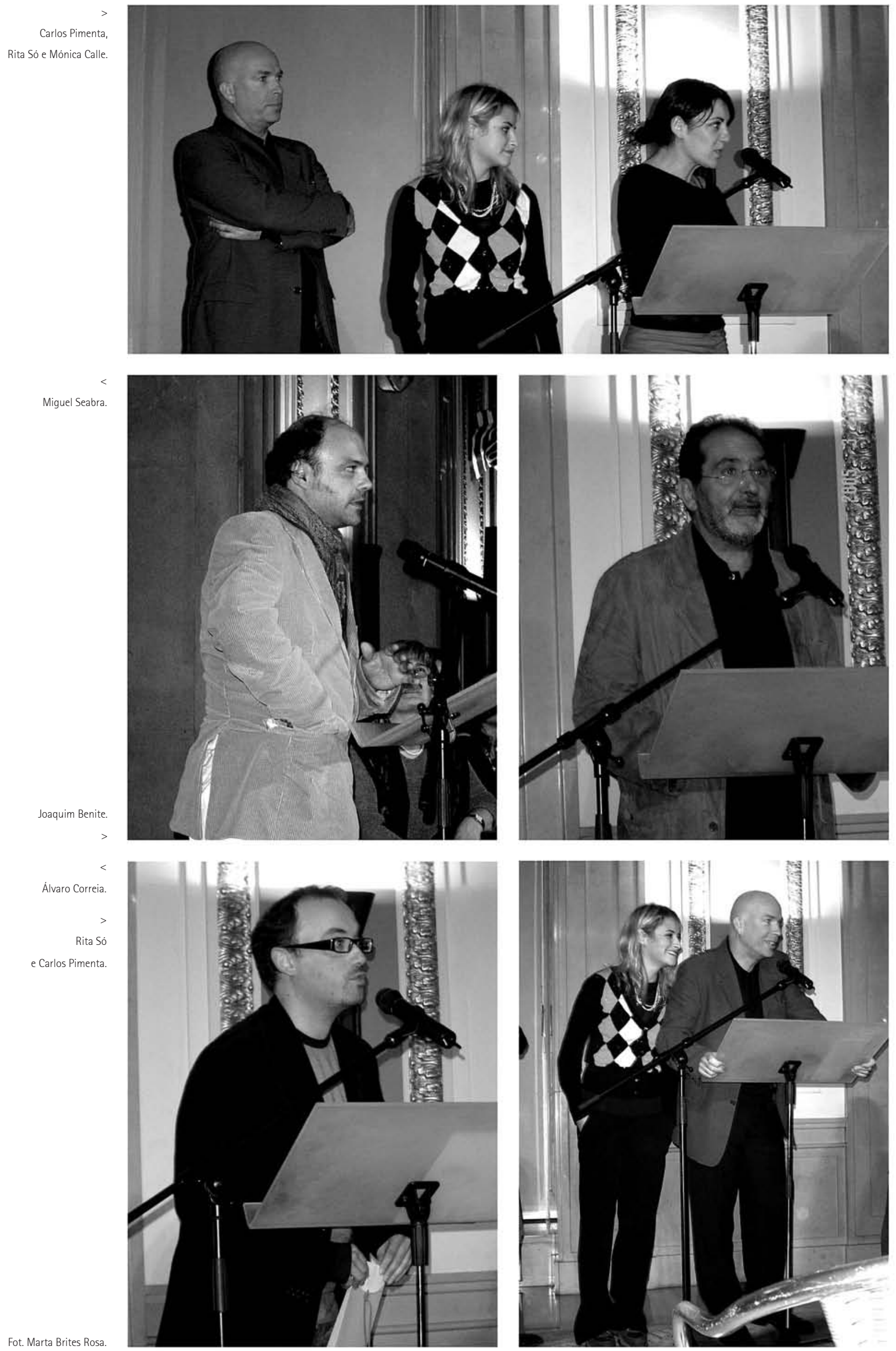

